\title{
In vivo Assessment of the Antinociceptive Activity of Ethanol Bark Extract of Thevetia peruviana (Family: Apocynaceae) in Swiss Albino Mice
}

\author{
Moumita Dey, Md. Lokman Hossain”, Most. Nazma Parvin \\ Department of Pharmacy, Stamford University Bangladesh, Bangladesh
}

Copyright $\mathrm{C} 2019$ by authors, all rights reserved. Authors agree that this article remains permanently open access under the terms of the Creative Commons Attribution License 4.0 International License

\begin{abstract}
Background: Thevetia peruviana, a common plant of Apocynaceae family has been used as Ayurvedic herbal medicine to treat hemorrhoids, hair loss, arthritis, and dysentery. The bark and leaf decoction has been used to loosen the bowels, as an emetic, and is said to be an effective curative agent for intermittent fevers. Aim of the study: The present study was an attempt to investigate the phytochemical constituents and to explore the antinociceptive activity of ethanol extract of the bark of Thevetia peruviana which is growing in Bangladesh. Methodology: The antinociceptive activity of ethanol extract of T. peruviana was evaluated by heat-induced (hot plate, tail immersion test) and chemical-induced (acetic acid induced writhing, formalin-induced nociception) pain models using Swiss albino mice as experimental animal. Results: The results of preliminary phytochemical screenings revealed that the extract contained alkaloids, tannins, terpenoids and flavonoids. For acetic acid-induced writhing test, the sample showed highest inhibition of writhing (40.04\%) at the dose of $400 \mathrm{mg} / \mathrm{kg}$ body weight, whereas standard drug (Diclofenac sodium) showed 65.6\% writhing inhibition. In formalin-induced nociception, extract of $T$. peruviana exhibited dose-dependent antinociceptive activity. On the other hand, ethanol extract of $T$. peruviana bark showed significant effect $(\mathrm{p}<0.05)$ in hot plate and tail immersion test in various phases. Conclusion: The ethanol extract of $T$. peruviana bark showed significant antinociceptive activity via multifactorial mechanism of action, indicating that the extract may be useful in the development of new analgesic drugs.
\end{abstract}

Keywords Thevetia Peruviana, Antinociceptive Activity, Acetic Acid-induced Writhing Test, Formalin-induced Nociception, Hot Plate, Tail Immersion

\section{Introduction}

Thevetia peruviana is an evergreen tropical shrub and small ornamental tree of the family Apocynaceae which is widely distributed in the tropics and subtropics. The leaves are spirally arranged, linear and glossy green in color. Flowers are bright yellow and funnel- shaped with 5 petals spirally twisted, slightly perfumed. The fruits are somewhat globular, slightly fleshy and have a diameter of $4-5 \mathrm{~cm}$ [1]. The fruits which are green in color become black on ripening. Each fruit contains a nut which is longitudinally and transversely divided. All parts of the plant are covered in waxy coating to reduce water loss (typical oleander). Broken twigs produce white milk sap. Its stem is cylindrical and green turning silver/gray as it ages. The plants are reproduced by seed. This plant is native of Central and South America, but now frequently grown throughout the tropical and sub-tropical regions. But it is cultivated all over the world including Bangladesh.

Almost all parts of the plant are used for therapeutic purpose. Thevetia peruviana contains a milky sap containing a compound called thevetin that is used as a heart stimulant. It contains heart-active "cardiac glycoside". Oleandrinis is used for treating cardiomyocytes. $T$. peruviana is utilized for the treatment of cancer. Studies have proved its in vitro potential for cancers of colon, leukaemia, prostrate, and pancreas. Long term use shows positive potential for the treatment of leiomyosarcoma, Ewing's sarcoma, cancer of breast. The bark and leaf decoction is taken to loosen the bowels, as an emetic, and is said to be an effective cure for intermittent fevers. Leaves and bark are macerated and is used to cure amenorrhea. Seeds possess cardiotonic, abortifacient, purgative and insecticidal action and are used for the treatment of dropsy and rheumatism. Latex of plant is applied to sores and tooth cavities, tincture of bark is used as bitter and cathartic, aqueous extract is applied to boils, blisters and skin diseases [2]. Seed kernel contains a phytosterolin and the 
glucosides, ahouain, kokilphin, thevetin, neriifolin, acetylneriifolin, thevefolin, theveneriin, cerebrin, peruvoside and rovuside and fatty oil constituting more than $62 \%$ of the kernel. Apigenin-5-methyl ether has been isolated from seed shells. A number of flavonol glycosides of kaempferol and quercetin have been isolated from the leaves. Leaves also contain polyhydroxy-dinormonoterpenoids and their apiosylglucosides. The toxins are cardenolides called Thevetin A and Thevetin B (Cerebroside). Seeds consist of around $60-65$ oil and $40-45 \%$ of protein $[2,3]$. As part of our ongoing research of traditional medicinal plants, the aim of this study is to investigate antinociceptive potential of Thevetia peruviana bark extract.

\section{Materials and Methods}

\subsection{Chemicals}

The drugs and chemicals used in the current study were Diclofenac Na (Novartis Bangladesh Ltd), Acetic acid, DMSO (Merck, Germany), Ethanol (95\%) and Distilled water.

\subsection{Plant Collection and Identification of the Plant}

The bark of Thevetia peruviana was collected from Mirzapur, Fenchugonj, Sylhet, Bangladesh in July 2016 and was identified by the taxonomist of the Bangladesh National Herbarium, Mirpur, Dhaka. The given accession number was DACB: 45045 Bangladesh National Herbarium. A voucher specimen had been deposited in the herbarium for future reference.

\subsection{Preparation of Plant Extract}

The collected barks were washed with clean water and separated from undesirable materials or plant parts. After shade drying the barks were grinded to make coarse powder by the help of a suitable grinder. Then the powder was merged in $700 \mathrm{~mL}$ of ethanol $(95 \%)$ and kept for a period of ten days accompanying occasional shaking and stirring. Then the whole mixture was filtered by a piece of clean, white cotton material followed by a second filtration through whatman filter paper. The solvent was evaporated at room temperature to obtain dried crude extract which was designated as EETP (Ethanol Extract of Thevetia peruviana).

\subsection{Experimental Animal}

Young Swiss-albino mice of both sex having age of 4-5 weeks, average weight 20-30 gm were used for the experiment. The mice were purchased from the Pharmacology Laboratory, Jahangirnagar University,
Savar, Dhaka. They were kept in standard environmental condition $\left(25.0 \pm 2{ }^{\circ} \mathrm{C}\right.$ temperature and $55-65 \%$ relative humidity and 12 hour light/ 12 hour dark cycle) for one week for acclimation after their purchase and fed standard food and water. The set of rules followed for animal experiment were approved by the institutional animal ethical committee (SUB/TAEC/11.01) of Stamford University Bangladesh.

\subsection{Drug and Treatments}

Diclofenac $\mathrm{Na}$ was used as positive control in writhing test, tail immersion, hot plate and formalin induced paw licking test. The mice in control group received vehicle (saline water) at the dose of $10 \mathrm{~mL}$ and $0.1 \mathrm{~mL} /$ mouse 30 minutes before experiments. Ethanol extract of the plant was administered to the test groups 30 minutes before the experiment.

\subsection{Phytochemical Screening}

The ethanol extract of T. peruviana was tested for the detection of alkaloids, terpenoids, flavonoids, tannins, steroids, glycoside, saponins, gum, reducing sugar, and combined reducing sugar by standard method [4].

\subsection{Acetic Acid Induced Writhing Test}

The acetic acid induced writhing method is an analgesic behavioral observation assessment method that demonstrates a noxious stimulation in mice $[4,5]$. The test consists of injecting the $0.7 \%$ acetic acid solution intraperitoneally and then observing the animal for specific contraction of body referred as 'writhing'. A comparison of writhing is made between positive control (Diclofenac sodium), negative control and test sample (given orally 30 minutes prior to acetic acid injection). If the sample possesses analgesic activity, the animal that received the sample will give lower number of writhing than the control, i.e. the sample having analgesic activity will inhibit writhing.

\subsection{Tail Immersion Test}

Sensitivity to acute thermal stimulation is the most common test used in live species pain research. For this reason, anti-nociceptive activity was determined by tail immersion method described by Gupta et al. [6]. The procedure is based on the observation that morphine like drugs selectively prolong to the reaction time of the typical tail withdrawal reflex in mice. One of two $\mathrm{cm}$ of tail of the mice pretreated with Diclofenac $\mathrm{Na}$ or plant extract were immersed in warm water kept constant at $55 \pm 5^{\circ} \mathrm{C}$. The latency between tail submersion and deflection of tail was recorded. A latency period of $20 \mathrm{sec}$ was maintained to avoid tail tissue damage in mice. The 
latency period of the tail-withdrawal response was taken as the index of antinociception and was determined at 30 , 60, 90 and 120 min after the administration of Diclofenac $\mathrm{Na}$ or sample.

\subsection{Hot- plate Test}

Hot plate test was used to measure the response latencies based on the procedure describe by Eddy et al. [7]. A hot plate is a heat conductive surface, such as porcelain or metal, is heated to a temperature that will induce a nociceptive response in an animal subject normally at $50-56^{\circ} \mathrm{C}$. Animals were placed into the hot plate chamber and the time of latency was defined as the time period between the zero point, when the animal was placed on the hot plate surface and the time when animal licked its back paw or jumped off to avoid thermal pain. The latent period of response was taken as the index of antinociception and was determined at the pre-treatment $30 \mathrm{~min}, 60 \mathrm{~min}, 90 \mathrm{~min}$ and $120 \mathrm{~min}$ after the administration of the sample and standard in the order to minimize the damage on the animal paws. The cut off time was taken as $20 \mathrm{sec}$. In this experiment, hot plate was maintained at $50 \pm 5^{\circ} \mathrm{C}$. The reaction time was recorded for animals pre-treated with DMSO at the dose of $10 \mathrm{~mL} / \mathrm{kg}$ b.w. (body weight) $30 \mathrm{~min}$ before orally as control, EETP at the doses of 50 and $100 \mathrm{mg} / \mathrm{kg}$ b.w., $30 \mathrm{~min}$ before and Diclofenac sodium at the dose of $25 \mathrm{mg} / \mathrm{kg}$ b.w. intraperitoneally, $15 \mathrm{~min}$ before.

\subsection{Formalin Induced Paw Licking Test}

A previously described method was used for the determination of antinociceptive activity by formalin induced paw licking test [8]. Animals were given $20 \mu \mathrm{L}$ of $2.5 \%$ formalin solution $(0.92 \%$ formaldehyde $)$ made up in saline was injected intraperitoneally in the ventral surface of the right hind paw. Mice were injected with 20 micro liter of a $2.5 \%$ formalin solution $(0.92 \%$ formaldehyde) made up in saline into a sub-plantar region of the right hind paw 60 min after EETP treatment and 15 min after injection of Diclofenac sodium. Licking of the injected paw was recorded as nociceptive response from 0-5 min (neurogenic phase) and 15-30 min (inflammatory phase) after formalin injection.

\section{Result}

\subsection{Phytochemical Screening}

Preliminary phytochemical screening of the ethanol extract of $T$. peruviana revealed the presence of various bioactive components namely, flavonoids, alkaloids, terpenoids and tannins and the result of phytochemical test has been summarized in in the table 1 .

Table 1. Result of phytochemical group test

\begin{tabular}{cc}
\hline Phytochemical group & Result \\
\hline Reducing sugar & - \\
\hline Combined reducing sugar & - \\
\hline Tannins & + \\
\hline Flavonoids & + \\
\hline Terpenoids & + \\
\hline Saponin & - \\
\hline Gums & - \\
\hline Steroids & - \\
\hline Alkaloids & + \\
\hline Glycosides & - \\
\hline
\end{tabular}

Here,$+=$ Presence, - = Absence

\subsection{Acetic Acid-induced Writhing Test}

In acetic acid-induced writhing test, the extract significantly inhibited writhing response in a dose dependent manner and was comparable to the reference drug, Diclofenac Na (Table 2, Figure1). A dose-dependent reduction in the number abdominal constriction was observed in animals treated with different concentration of ethanol extract of $T$. peruviana at the dose of 200 and 400 $\mathrm{mg} / \mathrm{kg}$ body weight. The inhibition of writhing was observed $22.7 \%$ and $40.04 \%$ at the dose of 200 and 400 $\mathrm{mg} / \mathrm{kg}$ body weight, respectively.

\subsection{Tail Immersion Test}

In tail immersion test, the time interval for the sample was 30 minutes. The tail withdrawal reflex time after administration of the T. peruviana was found to increase in Group-I $(50 \mathrm{mg} / \mathrm{kg}$ b.w. $)$ at $30 \mathrm{~min}$ and $90 \mathrm{~min}$ and Group-II $(100 \mathrm{mg} / \mathrm{kg}$ b.w. $)$ at $120 \mathrm{~min}$ for the sample (Table 3, Figure 2). 
In vivo Assessment of the Antinociceptive Activity of Ethanol Bark Extract of Thevetia peruviana

(Family: Apocynaceae) in Swiss Albino Mice

Table 2. Effect of T. peruviana extract in acetic acid-induced writhing test

\begin{tabular}{ccccccc}
\hline Animal group & $\begin{array}{c}\text { Mean of } \\
\text { writhing }\end{array}$ & \% Writhing & SD & SE & $\begin{array}{c}\text { \% Inhibition of } \\
\text { writhing }\end{array}$ & $\begin{array}{c}\text { t-test } \\
\text { (value of } \mathrm{p} \text { ) }\end{array}$ \\
\hline $\begin{array}{c}\text { Negative } \\
\text { control }\end{array}$ & 46.2 & 100 & 4 & 1.8 & 0 & $32.8, \mathrm{p}<0.05$ \\
\hline $\begin{array}{c}\text { Positive } \\
\text { control }\end{array}$ & 15.9 & 34.4 & 2.1 & 0.9 & 65.5 & $10.9, \mathrm{p}<0.05$ \\
\hline Group 1 & 35.7 & 77.27 & 3.09 & 1.38 & 22.7 & $26.3, \mathrm{p}<0.05$ \\
\hline Group 2 & 30.1 & 59.95 & 2.46 & 1.10 & 40.04 & \\
\hline
\end{tabular}

Values are expressed as, $\mathrm{SD}=$ Standard deviation, $\mathrm{SE}=$ Standard error, $\mathrm{P}<0.05$ compared with the control group (Dunnett's Test)

Negative control: saline water $10 \mathrm{~mL}$, Positive control: Diclofenac Sodium (25 mg/kg b.w.), Extract: (200 mg/kg b. w.), Extract: (400 mg/kg b.w.)

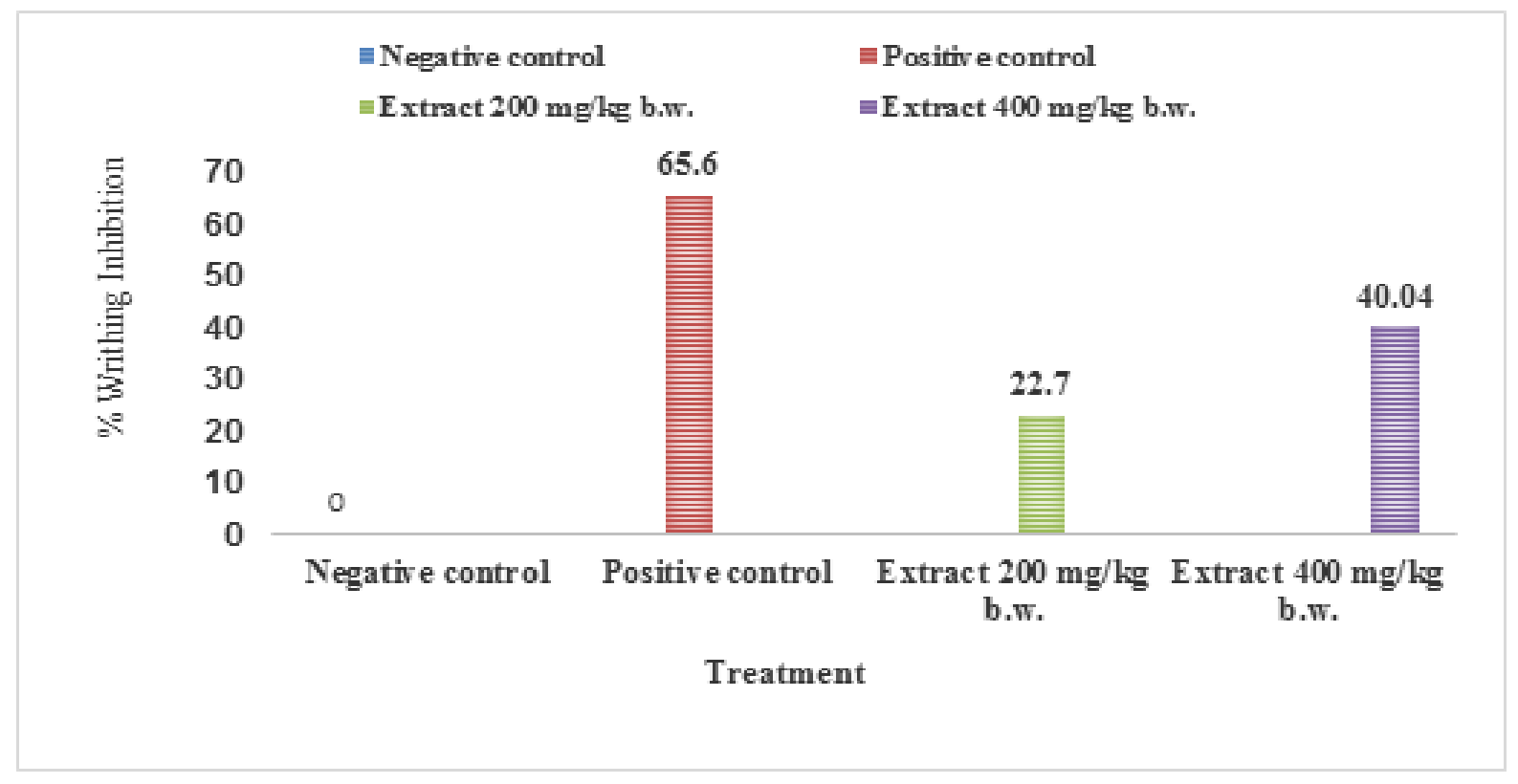

Figure 1. \% Writhing inhibition by the standard drug and sample

Table 3. Effect of T. peruviana in Tail Withdrawal Reflex test

\begin{tabular}{ccccccc}
\hline \multirow{2}{*}{ Treatment } & Dose & \multicolumn{5}{c}{ Response Times (in seconds) } \\
\cline { 3 - 7 } & $\mathrm{mg} / \mathrm{kg}$ b.w. & Pretreatment & $30 \mathrm{~min}$ & $60 \mathrm{~min}$ & $90 \mathrm{~min}$ & $120 \mathrm{~min}$ \\
\hline Negative Control & $\begin{array}{c}0.1 \\
\mathrm{~mL} / \mathrm{mouse}\end{array}$ & $0.756 \pm 0.129$ & $1.052 \pm 0.0128$ & $1.198 \pm 0.0102$ & $1.3 \pm 0.0130$ & $1.53 \pm 0.0228$ \\
\hline Positive control & 25 & $1.14 \pm 0.049$ & $1.174 \pm 0.030$ & $1.352 \pm 0.019$ & $1.918 \pm 0.115$ & $1.968 \pm 0.098$ \\
\hline Group-I & 50 & $0.31 \pm 0.046$ & $0.49 \pm 0.024$ & $0.934 \pm 0.023$ & $1.282 \pm 0.029$ & $1.46 \pm 0.055$ \\
\hline Group-II & 100 & $0.36 \pm 0.038$ & $0.81 \pm 0.152$ & $1.25 \pm 0.081$ & $1.543 \pm 0.129$ & $1.864 \pm 0.152$ \\
\hline
\end{tabular}

Values are expressed as Mean $\pm \mathrm{SE}(\mathrm{n}=5) ; \mathrm{P}<0.05$ compared with the control group (Dunnett's Test)

Control (saline water, $0.01 \mathrm{~mL} /$ Mouse), Positive Control: (Diclofenac Na, $5 \mathrm{mg} / \mathrm{kg}$ b.w.), Group I: Sample (50 mg/kg b.w.), Group II: Sample (100 mg/kg b.w.). 


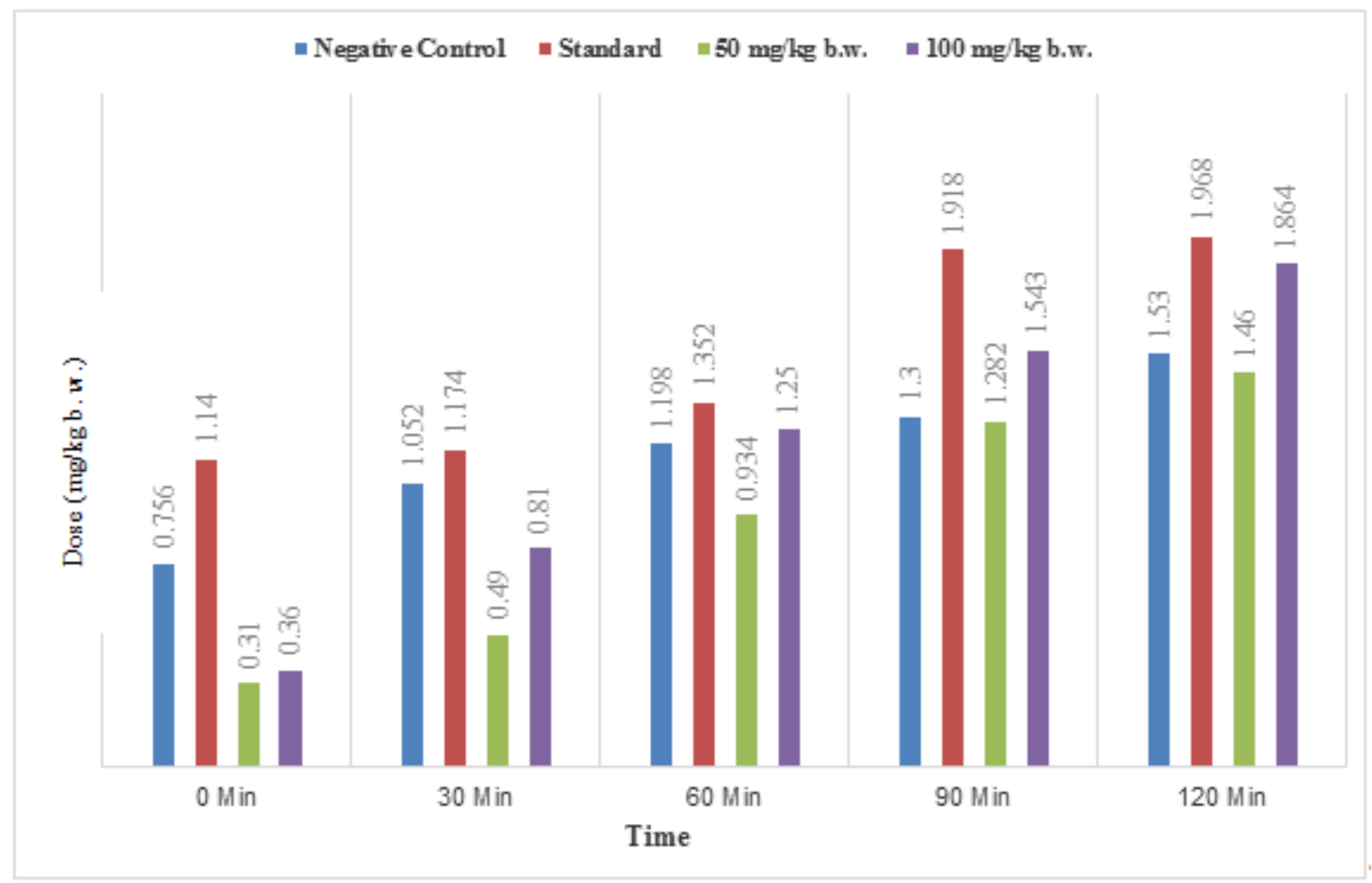

Figure 2. Effect of T. peruviana in tail withdrawal reflex test

\subsection{Hot- plate Test}

In hot plate test, the ethanol extract of $T$. peruviana displayed a moderate dose-dependent analgesic activity at the doses of 50 and $100 \mathrm{mg} / \mathrm{kg}$ body weight (Table 4, Figure 3 ).

Table 4. Effect of T. peruviana on extract on Tail Withdrawal Reflex test

\begin{tabular}{ccccccc}
\hline Test Group & $\begin{array}{c}\text { Dose } \\
\mathrm{mg} / \mathrm{kg} \text { b.w. }\end{array}$ & $0 \mathrm{~min}$ & $30 \mathrm{~min}$ & $60 \mathrm{~min}$ & $90 \mathrm{~min}$ & $120 \mathrm{~min}$ \\
\hline Negative Control & $0.1 \mathrm{~mL} / \mathrm{kg}$ & $0.52 \pm 0.026$ & $1.054 \pm 0.016$ & $1.2 \pm 0.012$ & $1.432 \pm 0.014$ & $1.754 \pm 0.109$ \\
\hline Positive Control & 25 & $2.89 \pm 0.423$ & $3.63 \pm 1.013$ & $3.87 \pm 0.497$ & $4.49 \pm 0.448$. & $4.62 \pm 0.516$ \\
\hline Group-I & 50 & $0.504 \pm 0.139$ & $0.982 \pm 0.194$ & $1.528 \pm 0.148$ & $1.92 \pm 0.176$ & $2.384 \pm 0.187$ \\
\hline Group-II & 100 & $0.884 \pm 0.175$ & $1.29 \pm 0.138$ & $1.69 \pm 0.056$ & $2.134 \pm 0.186$ & $2.584 \pm 0.179$ \\
\hline
\end{tabular}

Values are expressed as Mean $\pm \mathrm{SE},(\mathrm{n}=5), \mathrm{P}<0.05$ compared with the control group (Dunnett's Test)

Control: Saline water, Positive Control: Diclofenac Na (25 mg/kg b.w.), Group-I: Extract (50 mg/kg b.w.), Group-II: Extract (100 mg/kg b.w.) 


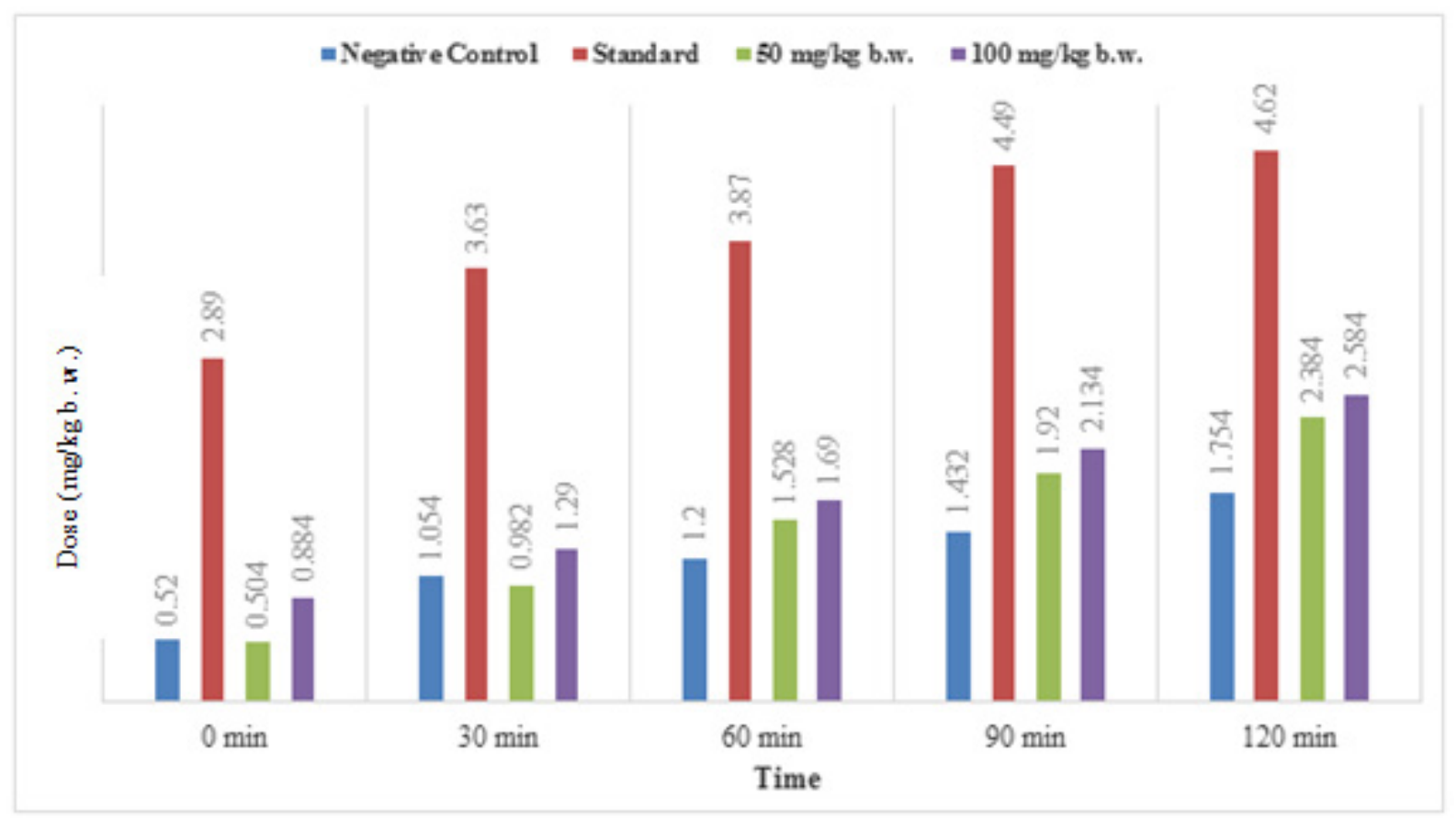

Figure 3. Effect of T. peruviana in acetic acid induced test

\subsection{Formalin Induced Paw Licking Test}

Oral administration of EETP at the doses of 200 and $400 \mathrm{mg} / \mathrm{kg}$ body weight significantly reduced the formalin-induced paw licking in both early and late phases of the test. Diclofenac sodium demonstrated complete inhibition of licking in late phase. EETP has shown a dose-dependent increase in the licking inhibition in both phases (Table 5, Figure 4).

Table 5. Effect of T. peruviana in formalin-induced paw licking Reflex test

\begin{tabular}{cccccc}
\hline \multirow{2}{*}{ Treatment } & Dose $(\mathrm{mg} / \mathrm{kg})$ & \multicolumn{2}{c}{ Licking Time (In Sec.) } & \multicolumn{2}{c}{ Inhibition (\%) } \\
\cline { 3 - 6 } & & Early Phase & Late Phase & Early Phase & Late Phase \\
\hline \multirow{2}{*}{ Negative Control } & $\begin{array}{c}0.1 \\
\mathrm{~mL} / \mathrm{mouse}\end{array}$ & $27.8 \pm 4.21$ & $5 \pm 0.71$ & - & - \\
\hline Positive Control & 25 & $24.4 \pm 0.51$ & $9.4 \pm 0.93$ & 75.6 & 90.6 \\
\hline Group I & 200 & $21.4 \pm 1.21$ & $3.8 \pm 0.9$ & 78.6 & 96.2 \\
\hline Group II & 400 & $21.8 \pm 0.86$ & $2.4 \pm 0.4$ & 78.2 & 97.6 \\
\hline
\end{tabular}

Values are expressed as Mean $\pm \mathrm{SE},(\mathrm{n}=5), \mathrm{P}<0.05$ compared with the control group (Dunnett's Test)

Control: Saline water, Positive Control: Diclofenac Na (25 mg/kg b.w.), Group-I: Sample (200 mg/kg b.w.), Group-II: Sample (400 mg/kg b. w.) 


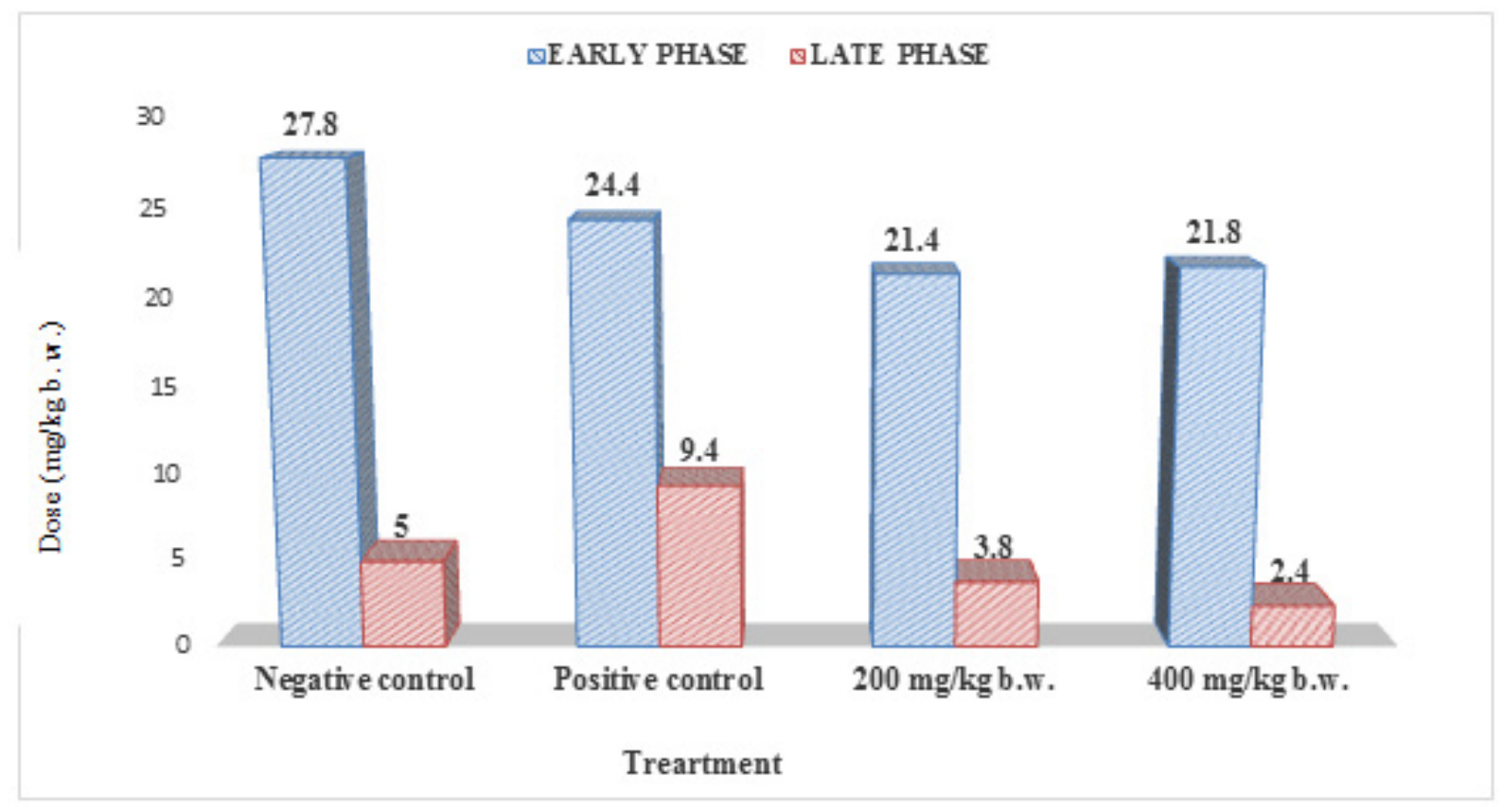

Figure 4. Effect of T. peruviana in Formalin-induced Paw Licking Test

\section{Discussion}

Pain is a distressing feeling often caused by intense or damaging stimuli. Nociceptive pain is the most familiar because it arises from damaged tissue, like a cut or a burn. Pain perception in the brain involves two different pain systems: one of pain perception and one of pain modulation. Treating pain is one of the most significant challenges world-wide. Currently, management of pain is mainly based on chemical medicine including non-steroidal anti-inflammatory drugs and glucocorticoids, which possess various side effects such as cardiotoxicity, hepatotoxicity and immunological dysfunction. Thus, natural anti-inflammatory agents with their precise understanding of synergistic action have attracted the attention of many researchers for treatment of enteritis, arthritis, skin inflammation and so on [9].

Our present study suggests that identified phytochemicals from ethanol extract of Thevetia peruviana can be a promising source of novel compound(s) effective against central and peripheral painful condition. The ethanol extract of the plant showed the presence of some essential phytochemicals, namely, flavonoids, alkaloids, terpenoids and tannins.

Acetic acid induced writhing model is most extensive method for assessing in vivo analgesic activity in mice. In this model, peripherally performing analgesic activity of the sample is assessed by inducing writhing through the sensitization of locally active peritoneal receptors by the release of endogenous substances. Generally, acetic acid liberates several endogenous substances like cyclooxygenase (COX), prostaglandins (PGs), lipoxygenase (LOX), histamine, serotonin, bradykinin, substance $\mathrm{P}$, and cytokines (IL-1 $\beta$, IL-8, TNF- $\alpha$ ) in peripheral tissue fluid which are responsible for inducing pain by stimulating nerve endings [10]. Locally active peritoneal receptors activate the abdominal constrictions response [11]. The abdominal constriction response induced by acetic acid is a responsive procedure to estimate peripherally acting analgesics [12]. The expression of these mediators causes the excitation of primary afferent nociceptors entering in the dorsal horn of the spinal cord as well as the thalamus at central and peripheral nervous system. Our experimental findings also provide the supporting evidences about the use of Thevetia peruviana in painful and inflammatory conditions.

The hot plate and tail immersion tests are extensively recognized methods for understanding the centrally acting antinociceptive activity. In our present study, EETP at 50 and $100 \mathrm{mg} / \mathrm{kg}$ body weight doses exhibited antinociceptive effects in the hot plate and tail immersion tests by increasing hot plate latency as well as tail withdrawal response. The central antinociceptive activity of EETP may due to its effect on $\mu$-opioid receptors of spinal as well as the supraspinal system. EETP containing compounds may diminish the activity of adenylyl cyclase which is accountable for the $\mathrm{Ca}^{2+}$ influx. The antinociceptive effect exerts through hyperpolarization of the nerves by decreasing cAMP level, $\mathrm{K}^{+}$efflux, and subsequently

In Formalin-induced paw licking test, the antinociceptive property of EETP was found as significant and dose-dependent (200 and $400 \mathrm{mg} / \mathrm{kg}$ body weight) at both neurogenic (early phase) and inflammatory (late phase) pain responses caused by formalin in mice. EETP produces antinociception in both phases of the formalin-induced nociception test. 
The presence of flavonoids, alkaloids, terpenoids and tannins in the ethanol extract of Thevetia peruviana may be accountable for antinociceptive activity, because it is well established that these phytochemicals may be responsible for a wide range of bioactivities [13-18]. Flavonoids and alkaloids interact directly with the prostaglandin system. Terpenoids and tannins exert anti-inflammatory effect by modulating critical cell signaling pathways involved in the inflammatory response of the body such as nuclear transcription factor-kappa B (NF- $\kappa B$ ) activation. NF- $\kappa B$ plays an important role in the regulation of immune and inflammatory responses and this is why it has become a major target in drug discovery [19].

\section{Conclusions}

The above studies demonstrate that oral and intraperitoneal administration of ethanol extract of Thevetia peruviana bark elicits a potent dose dependent antinociceptive effect in both chemical and thermal-induced nociception models. Further studies are required to isolate and purify the bioactive compound(s) and elucidate the underlying molecular mechanisms of action. It may be a potential source of lead compound(s) in drug development and discovery process.

\section{Declarations}

\section{Acknowledgements}

The authors are thankful to the Department of Pharmacy, Stamford University Bangladesh to permit us for using the facilities of the Pharmacology and Phytochemistry Laboratory.

\section{Ethics Approval and Consent to Participate}

All the experimental mice were treated following the Ethical Principles and Guidelines for Scientific Experiments on Animals (1995) postulated by the Swiss Academy of Medical Sciences and the Swiss Academy of Sciences. The Institutional Animal Ethical Committee (SUB/TAEC/11.01) of Stamford University Bangladesh permitted all experimental rules.

\section{Competing Interests}

The authors declare that they have no conflict of interests.

\section{Consent for Publication}

Not applicable

\section{Funding}

This research was not funded by any funding agencies. All the studies had been self-funded by author and co-authors.

\section{Authors' Contributions}

Moumita Dey conceived, planned, did literature searches and performed the experiments. Md. Lokman Hossain contributed to data analysis, interpreted results, manuscript writing and supervised the experiments. Most. Nazma Parvin was the co-supervisor and finally edited the manuscript. All authors read and approved the final manuscript.

\section{REFERENCES}

[1] K. K. Samal, H. K. Sahu, P. Gopalakrishnakone. Clinico-pathological study of Thevetia peruviana (yellow oleander) poisoning. J. Wilderness Med. 1992; 3(4): 382-386.

[2] T. Ahmad, A. T. Hamid, A. Sharma, U. Bhardwaj. Thevetia peruviana: A Multipurpose Medicinal Plant- A review. Int. J. Adv. Res. 2017; 5(8), 486-493.

[3] N. Rahman, H. Rahman, M. Haris, R. Mahmood. Wound healing potentials of Thevetia peruviana: Antioxidants and inflammatory markers criteria. J. Tradit. Complement Med. 2017; 7: 519-525.

[4] U. K. Karmakar, S. Sultana, S. Nishi, N. N. Biswas, L. Hossain, S. Sheikh. Antioxidant, Analgesic, Antimicrobial, and Anthelmintic Activity of the Dried Seeds of Bixa orellana (L). Int. J. Pharm. 2018; 8 (1):150-163.

[5] M. L. Hossain, S. Sultana. In-vivo Assessment of Neuropharmacological Activity of Methanol Bark Extract of Mimosa pudica in Mice. Adv. Pharmacol. Pharm. 2019; $7(2)$.

[6] A. K. Gupta, D. Parasar, A. Sagar, V. Choudhary, B. S. Chopra, R. Garg, N. Khatri. Analgesic and anti-inflammatory properties of gelsolin in acetic acid induced writhing, tail immersion and carrageenan induced paw edema in mice. PloS one. 2015; 10(8):e0135558.

[7] N. B. Eddy, D. Leimbach. Synthetic analgesics. II. Dithienylbutenyl and dithienylbutylamines. J. Pharmacol. Exp. Ther. 1953; 107(3):385-393.

[8] A. Tjolsen,O. G. Berge, S. Hunskaar, J. H. Rosland, K. Hole. The formalin test: an evaluation of the method. Pain. 1992; 51(1):5-17.

[9] Y. Nie, Q. Lin, F. Luo. Effects of non-starch polysaccharides on inflammatory bowel disease. Int. J. Mol. Sci. 2016, 18, 1372.

[10] J. M. Barbosa-Filho, M. R. Piuvezam, M. D. Moura, M. S. Silva, K. V. B. Lima, E. V. L. da-Cunha, I. M. Fechine, O. S. Takemura. Anti-inflammatory activity of alkaloids: A 
twenty-century review. Revista Brasileira de Farmacognosia 2006, 16(1):109-139.

[11] R. M. Gene, L. Segura, T. Adzet. Heterotheca inuloides: anti-inflammatory and analgesic effects. J Ethnopharmacol. 1998; 60:157-162.

[12] G. A. Bentley, S. H. Newton, J. Starr. Studies on the antinociceptive action of agonist drugs and their interaction with opioid mechanisms. Br J Pharmacol 1983; 79:125-134.

[13] A. A. Adedapo, M. O. Sofidiya, V. Maphosa, B. Moyo, P. J. Masika, A. J. Afolayan. Anti-inflammatory and analgesic activities of the aqueous extract of Cussonia paniculata stem bark. Rec Nat Prod 2008; 2:46-53.

[14] N. S. Parmar, M. M. N. Ghosh. Current trends in flavonoid research. Indian J Pharm 1978; 12: 213-228.

[15] J. Choi, H. J. Jung, K. T. Lee, H. J. Park. Antinociceptive and antiinflammatory effects of saponin and sapogenin obtained from the stem of Akebia quinata. J Med Food 2005; 8:78-85.

[16] K. R. Narayana, M. S. Reddy, M. R. Chaluvadi, D. R. Krishna. Bioflavanoids classification, pharmacological, biochemical effects and therapeutic potential. Indian J Pharmacol 2001; 33:2-16.

[17] A. Ahmadiani, J. Hosseiny, S. Semnanian, M. Javan, F. Saeedi, M. Kamalinejad. Antinociceptive and anti-inflammatory effects of Elaeagnus angustifolia fruit extract. J Ethnopharmacol 2000; 72:287-292.

[18] A. Azab, A. Nassar, A. N. Azab. Anti-Inflammatory Activity of Natural Products. Molecules. 2016, 21, 1321.

[19] B. D. L. Heras, S. Hortelano. Molecular Basis of the Anti-Inflammatory Effects of Terpenoids. Inflammation \& Allergy - Drug Targets. 2009; 8(1):28-39. 